\title{
Mereduksi Perilaku Agresif Anak Melalui Bimbingan Kelompok dengan Permainan Tradisional Di Daerah Pesisir
}

\author{
Sahrestia Kartianti ${ }^{1}$, Frandian Laluba $^{2}$, Sau Tjepa $^{3}$, Richard Laluba $^{4}, K_{\text {Krisdayanti }}$ \\ Halimongo ${ }^{5}$,Yoksan Balitang ${ }^{6}$
}

\author{
Program Studi Bimbingan dan Konseling, \\ Fakultas Ilmu Sosial dan Kependidikan, \\ Universitas Hein Namotemo \\ Email : sahrestia.kartianti07@gmail.com
}

\begin{abstract}
Abstrak
Perilaku agresif muncul pada saat stimulus dan respon bertindak secara bersamaan. Perilaku agresif berpengaruh sangat besar terhadap perkembangan karakter anak, sehingga diperlukan upaya untuk mereduksi perilaku tersebut. Hal tersebut tidak hanya terjadi di daerah perkotaan saja, melainkan di daerah pesisir yaitu daerah Gonga Pantai, kecamatan Tobelo Timur, kabupaten Halmahera Utara provinsi Maluku Utara. Di daerah Gonga Pantai, perilaku anak cenderung menunjukkan perilaku agresif dalam proses interaksi sosialnya dengan orang lain. Hal tersebut ditunjukkan dengan adanya perilaku agresif anak usia 7-9 tahun sangat rentan seperti memukul, memaki ,mencubit, menendang, dan menghina. Mereduksi perilaku agresif pada anak dapat dilakukan melalui bimbingan kelompok dengan menggunakan permainan-permainan tradisional Halmahera Utara. Permainan tradisional yang digunakan yaitu perang nama, leng kali leng, tuan dosi, jilo-jilo dan gate-gate kaki. Penelitian ini bertujuan untuk mereduksi perilaku agresif anak melalui bimbingan kelompok dengan permainan tradisional di daerah pesisir. Penelitian ini menggunakan pendekatan penelitian eksperimen dengan desain one group pre-post test. Hasil dari penelitian ini adalahterjadi penuruan skor pada saat setelah diberi perlakuan (post test) bimbingan kelompok dengan permainan tradisional. Hasil Uji $t$ sebesar 6,8374 >0,05 menunjukkan bahwa ada perbedaan antara sebelum diberi perlakuan dan sesudah diberiperlakuan.
\end{abstract}

Kata Kunci: Perilaku agresif,permainan tradisional,bimbingan kelompok,daerah pesisir.

\begin{abstract}
Aggressive behavior occurs when the stimulus and response act simultaneously. Aggressive behavior has a very big influence on the development of children's character, so it needs an effort to reduce the behavior. This does not only occur in urban areas, but in coastal areas, namely GongaPantai, East Tobelo sub-district, North Halmahera district, North Maluku province. In the GongaPantai area, children's behavior tends to show aggressive behavior in the process of social interaction with others. This is indicated by the aggressive behavior of children aged 7-9 years who are very vulnerable such as hitting, cursing, pinching, kicking, and insulting. Reducing aggressive behavior in children can be done through group guidance by using traditional North Halmahera games. The traditional games used are perangnama, leng kali leng, tuandosi, jilo-jilo and gate-gate kaki. This study aims to reduce the aggressive behavior of children through group guidance with traditional games in coastal areas. This study uses an experimental research approach with one group pre-post test design. The results of this study are a decrease in scores after being given a treatment (post test) group guidance with traditional games. $\mathrm{T}$ Test results of $6.8374>0.05$ indicate that there is a difference between before being treated and after being treated.
\end{abstract}

Keywords: Aggressive behavior, traditional games, group guidance, coastal areas.

\section{PENDAHULUAN}

Perilaku agresif merupakan suatu tindakan individu yang bertujuan melukai atau menyakiti individu yang lain. Perilaku agresif muncul pada saat stimulus dan respon bertindak secara bersamaan. Menurut Moore dan Fine (dalam Restu 2013:243), merupakan tingkah laku kekerasan secara fisik ataupun secara verbal terhadap individu lain atau terhadap objekobjek. Penyebab munculnya perilaku agresif ini akibat adanya situasi yang tidak menyenangkan atau menganggu individu yang saling berinteraksi sehingga mempengaruhi kondisi internalseseorang.

Perilaku agresif berpengaruh sangat besar terhadap perkembangan karakter anak, sehingga diperlukan upaya untuk mereduksi perilaku tersebut. Hal tersebut tidak hanya terjadi di daerah perkotaan saja, melainkan di daerah pesisir yaitu daerah Gonga Pantai, kecamatan Tobelo Timur, kabupaten Halmahera Utara provinsi Maluku Utara. Halmahera Utara adalah salah satu wilayah yang terdapat di 
Provinsi Maluku Utara, yang memiliki beragam potensi sumber daya alam (SDA) dan budaya. Wilayah Halmahera Utara, terdiri atas dataran tinggi, dataran rendah, dan pesisir. Kehidupan masyarakat pesisir berbeda dengan kehidupan masyarakat pada umumnya. Kehidupan masyarakat pesisir lebih menggantungkan kehidupannya pada pekerjaan hasil laut, namun di sisi lain masyarakat di daerah pesisir tidak hanya menggantungkan hidupnya pada hasil laut saja,tetapi ada juga dari hasil lainnya misalnya di daerah Gonga Pantai yang mayoritas pekerjaannya antara lain pegawai,pegawai negeri sipil, petani dan sebagainya.

Di daerah Gonga Pantai, perilaku anak cenderung menunjukkan perilaku agresif dalam proses interaksi sosialnya dengan orang lain. Hal tersebut ditunjukkan dengan adanya perilaku agresif anak usia 7-9 tahun sangat rentan seperti memukul, memaki ,mencubit, menendang, dan menghina. Hal ini menunjukkan bahwa,tingkat keagresifan pada anak usia dini sudah ada dan akibatnya pada perkembangan perilaku anak cenderung ke hal-hal yang negatif. Penyebab dari perilaku agresi tersebut disebabkan oleh beberapa faktor diantaranya kurangnya pengawasan orang tua, lingkungan yang kurang komukatif, imitasi perilaku anak dari orang dewasa dan temansepermainan.

Dilihat dari latar belakang pendidikan orang tua yang mayoritas pegawai, seharusnya perilaku agresif pada anak tidak muncul mengingat latar belakang pendidikan orang tua yang tinggi (PNS, Guru, dan Pendeta). Hal ini menunjukkan bahwa faktor orang tua yang kurang memperhatikan anaknya dalam hal pengawasan, sehingga menimbulkan keprihatinan yang mendalam terhadap perilaku anak sebagai generasi penerus bangsa.

Salah satu upaya yang diperlukan mereduksi perilaku agresif anak yaitu melalui "bimbingan kelompok". Bimbingan kelompok merupakan upaya bantuan kepada individu-individu dalam suasana kelompok yang bersifat pencegahan dan pengentasan masalah, dan diarahkan kepada pemberian kemudahan dalam rangka perkembangan dan pertumbuhan anak. Pelaksanaan bimbingan kelompok dapat berjalan sesuai dengan tujuannya, yaitu untuk pengembangan dan pertumbuhan anak maka dibutuhkan adanya inovasi-inovasi baru dalam hal mereduksi perilaku agresif anak.

Dilihat dari tahap-tahap perkembangan anak, diusia 4-9 tahun sangat beresiko tinggi dalam hal penanaman perilaku anak karena dalam perilaku anak cenderung meniru orang dewasa. Oleh karena itu, dibutuhkan suatu cara atau metode untuk menanggulangi kecenderungan resiko tersebut. Pada dasarnya masa anak adalah masa yang identik dengan bermain. Pada umumnya dalam bermain, anak terlibat dalam suatu permainan. Misbah dalam Nur (2013:90) menyimpulkan bahwa permainan adalah situasi bermain yang terkait dengan beberapa aturan atau tujuan tertentu, yang menghasilkan kegiatan dalam bentuk tindakan bertujuan.Menurut Patras (2016:1) menjelaskan bahwa ada permainan' bamila dan raja-raja ', permainan ini secara khusus hanya dimainkan oleh anak-anak yang ada di desa Duma Galela, karena permainan ini hanya bisa dimainkan di Telaga Duma. Kekhususan inilah yang membuat setiap permainan rakyat itu menjadi sangat indah dan mengandung nilai sejarah dan budaya yang sangat tinggi. Ada juga permainan yang berasal dari "Makian dan Galela" yang permainannya mempunyai ciri khas tersendiri. Seperti permainan Koba-Koba Kenari yang berasal dari Makian, alat permainan yang digunakan adalah kenari dan Makian adalah salah satu daerah penghasil buah kenari di Halmahera Utara. Hal tersebut menunjukkan bahwa Halmahera Utara memiliki beranekaragam permainan tradisional kurang lebih 70 permainan (Patras,2016:1-3).

Hasil penelitian Kurniati dalam Nur (2013:89) menunjukkan bahwa permainan anak tradisional dapat menstimulasi anak dalam mengembangkan kerjasama, membantu anak menyesuaikan diri, saling berinteraksi secara positif, dapat mengkondisikan dalam mengontrol diri, mengembangkan sikap empati terhadap teman, menaati aturan, serta menghargai orang lain. Sehingga dapat dipahami bahwa permainan tradisional berdampak sangat baik dalam membantu mengembangkan keterampilan emosi dan sosial anak.

Agresif menurut Baron dalam Restu (2013:247) adalah tingkah laku yang dijalankan oleh individu dengan tujuan melukai atau mencelakakan individu lain yang tidak menginnginkan datangnya tingkah laku tersebut. Sehingga tingkah laku agresif dapat dikatakan sebagai tingkah laku pelampiasan dari perasaan frustasi untuk mengatasi perlawanan dengan kuat atau menghukum orang lain, yang ditujukan untuk melukai pihak lain secara fisik maupun psikologis pada orang lain yang dapat dilakukan secara fisik maupun verbal. Perilaku agresif pada anak usia 49 tahun terjadi karena banyak faktor yang menyebabkan, mempengaruhi, atau memperbesar peluang munculnya seperti faktor biologis, temperamen yang sulit, pengaruh yang negatif, penggunaan narkoba, pengaruh tayangan kekerasan, dan lainsebagainya. Untuk mengatasi hal tersebut dibutuhkan suatu layanan dalam bimbingan dan konseling. Layanan tersebut salah satunya adalah layanan bimbingan kelompok.

Bimbingan kelompok adalah salah satu kegiatan layanan yang paling banyak dipakai karena lebih efektif. Banyak orang yang mendapatkan layanan sekaligus dalam satu waktu. Layanan ini juga sesuai dengan teori belajar karena mengandung aspek sosial yaitu belajar bersama. Peserta layanan akan berbagi ide, gagasan, pendapat serta pengalaman dan saling mempengaruhi untuk berkembang menjadi manusia seutuhnya (Petruz,2012:96). Selanjutnya Winkel (2012: 547) menjelaskan bahwa bekerja dalam kelompok atau bekerja dengan kelompok (group work) menunjuk pada seperangkat metode 
dan teknik yang untuk mendampingi suatu kelompok dalam meningkatkan cara dan mutu berinteraksi sedimikian rupa, sehingga menunjang pencapain tujuan yang ditetapkan dan pengembangan kepribadian masing-masing anggota yang tergabung dalam suatu kelompok.

Bimbingan kelompok dalam prakteknya dapat menggunakan berbagai teknik ataupun pendekatan tertentu yaitu salah satunya menggunakan permainan tradisional. Iswinarti (2010:41) Permainan tradisional merupakan kekayaan budaya bangsa yang mempunyai nilainilai luhur untuk dapat diwariskan kepada anakanak sebagai generasi penerus.Hasil kajian penelitiannya bahwa permainan anak tradisional mempunyai hubungan yang erat dengan perkembangan intelektual, sosial, emosi, dan kepribadian anak. Karena masa anak adalah masa yang identik dengan bermain dan terlibat dalam suatu permainan. Permainan tradisional berdampak sangat baik dalam membantu mengembangkan keterampilan emosi dan sosial anak.

\section{METODOLOGI PENELITIAN}

Penelitian ini adalah penelitian ekperimen dengan menggunakan desain one group pretestposttest design. Menurut Sugiyono (2013:111) bahwa uji keefektifan dalam desain one group pretest-posttest design adalah dengan membandingkan hasil pre test dan post test satu kelompok subyek penelitian saja tanpa ada kelompok pembanding. Berdasarkan uraian yang telah dikemukakan maka desain uji keefektifan one group pre test post test design yang digunakan dapat digambarkan sebagaiberikut:

Populasi dalam penelitian ini adalah 16 orang, dimana yang menjadi sampelnya adalah 9 orang yang mendapat perlakuan. Teknik pengumpulan data yang digunakan adalah wawancara, observasi, dan juga skala perilaku agresif sebanyak 48 butir pernyataan. Teknik analisis data yang digunakan dalam penelitian ini adalah analisis deskriptif pada pelaksanaan layanan bimbingan kelompok dengan permaianan tradisional dan analisis keefektifan bimbingan kelompok dengan permainan tradisional untuk mereduksi perilaku agresif anak di daerah pesisir dengan menggunakan uji statstik yaitu uji-t.

\section{HASIL PENELITIAN DAN PEMBAHASAN}

Berdasarkan hasil observasi anak-anak di dusun Gonga Pantai didapatkan gambaran terhadap perilaku agresif anak yang menunjukkan beberapa perilaku dari sebagian besar anak sebagai berikut: Memukul, mencubit, menampar, menjahili teman, membentak, menghina, memaki, acuh tak acuh, menolak menjawab pertanyaan, mengejek, tidak mau mendengar kritikan orang lain terhadapdirinya. Hasil tersebut menunjukkan bahwa anak-anak sejak dini sudah melakukan perilaku agersif, namun hal itu tidak disadari dan dianggap biasa bagi anak-anak tersebut.

Dalam penelitian ini, proses bimbingan kelompok dengan permainan tradisional dilakukan sebanyak 8x pertemuan dengan mengikuti tahapan atau prosedur dalam bimbingan kelompok yang terdiri dari tahap pembentukan, tahap peralihan, tahap kegiatan, tahap penyimpulan dan tahap penutupan serta menginternalisasikan permainan tradisional ke dalamnya. Permainan tradisional tersebut adalah permainan tradisional khas Halmahera Utara yaitu perang nama, leng kali leng, tuan dosi, jilo-jilo dan gate-gate kaki.

a. Pertemuan I. Pelaksanaan penelitian menggunakan prosedur dalam bimbingan kelompok. Dalam pertemuan pertama ini diberikan materi tentang "Persahabatan" oleh pemimpin kelompok. Pada pertemuan ini, anak-anak dalam kelompok diobservasi dengan menggunakan lembar observasi perilaku agresif anak dan menunjukkan hasil bahwa anak-anak masih melakukan perilakuagresif.

b. Pertemuan II. Pelaksanaan penelitian menggunakan prosedur dalam bimbingan kelompok. Dalam pertemuan kedua ini diberikan materi tentang "Persahabatan" oleh pemimpin kelompok dan juga praktek permainan tradisional Halmahera Utara(JiloJilo).

c. Pertemuan III. Pelaksanaan penelitian menggunakan prosedur dalam bimbingan kelompok. Dalam pertemuan kedua ini diberikan materi tentang "Persahabatan" oleh pemimpin kelompok dan juga praktek permainan tradisional Halmahera Utara (TuanDosi).

d. Pertemuan IV. Pelaksanaan penelitian menggunakan prosedur dalam bimbingan kelompok. Dalam pertemuan kedua ini diberikan materi tentang "IPTEKS" oleh pemimpinkelompok.

e. Pertemuan $V$. Pelaksanaan penelitian menggunakan prosedur dalam bimbingan kelompok. Dalam pertemuan kedua ini diberikan materi tentang "IPTEKS" oleh pemimpin kelompok dan juga praktek permainan tradisional Halmahera Utara (Gate-Gate Kaki). Pada pertemuan ini, perilaku agresif anak sudah cenderungmenurun.

f. Pertemuan VI. Pelaksanaan penelitian menggunakan prosedur dalam bimbingan kelompok. Dalam pertemuan kedua ini diberikan materi tentang "IPTEKS" oleh pemimpin kelompok dan juga praktek permainan tradisional Halmahera Utara (Perang Nama).

g. Pertemuan VII. Pelaksanaan penelitian menggunakan prosedur dalam bimbingan kelompok. Dalam pertemuan kedua ini diberikan materi tentang "Kekeluargaan" oleh pemimpinkelompok.

h. Pertemuan VIII. Pelaksanaan penelitian menggunakan prosedur dalam bimbingan kelompok. Dalam pertemuan kedua ini diberikan materi tentang "Kekeluargaan" oleh pemimpin kelompok dan juga praktek permainan tradisional Halmahera Utara (Leng Kali Leng).Pada pertemuan terakhir yang 
dilakukan, hasil observasi menunjukkan bahwa anak-anak tidak lagimelakukan perilaku agresif setelah diberiperlakuan.

Sebelum memberikan perlakuan, terlebih dilakukan pre test pada seluruh anak yang menjadi populasi dalam penelitian ini. Selanjutnya diambil 9 orang yang memiliki kriteria perilaku agresif yang sangat tinggi dan tinggi. Perlakuan yang diberikan merupakan upaya untuk mengurangi perilaku agresif sejak dini pada anak dengan menyesuaikan tahap perkembangan anak. Maka permainan tradisional digunakan sebagai cara untuk mendekatkan anak dengan sesama temannya atau orang lain dalam berperilaku. Permaianan tradisional sering digunakan oleh anak-anak termasuk anak-anak yang tinggal di daerah pesisir seperti di Desa Gonga Dusun Gonga Pantai. Mereka memainkan permainan tersebut dengan alat seadanya bahkan tanpa alat atau menggunakan anggota tubuh.

Hasil uji $t$ menjukkan bahwa terjadi penuruan skor pada saat setelah diberi perlakuan (post test) bimbingan kelompok dengan permainan tradisional. Hasil Uji $t$ sebesar 6,8374 >0,05 maka ada perbedaan antara sebelum diberi perlakuan dan sesudah diberiperlakuan. Hasil tersebut dijabarkan dalam tabel berikut :

Tabel.Hasil Pre test dan Post test perilaku agresif anak sebelum dan setelah diberi perlakuan

\begin{tabular}{|l|l|l|l|l|l|l|}
\hline No & Nama & $\begin{array}{c}\text { Pre } \\
\text { Test }\end{array}$ & Ket & $\begin{array}{c}\text { Post } \\
\text { Test }\end{array}$ & Ket & $\begin{array}{c}\text { Selisih } \\
\text { Skor }\end{array}$ \\
\hline 1 & NV & 118 & T & 100 & T & 18 \\
\hline 2 & AR & 110 & T & 98 & R & 12 \\
\hline 3 & VS & 120 & T & 104 & T & 16 \\
\hline 4 & AL & 118 & T & 110 & T & 8 \\
\hline 5 & AI & 116 & T & 106 & T & 10 \\
\hline 6 & RN & 112 & T & 96 & R & 16 \\
\hline 7 & DS & 114 & T & 98 & R & 16 \\
\hline 8 & JN & 118 & T & 110 & T & 18 \\
\hline 9 & MV & 118 & T & 106 & T & 12 \\
\hline
\end{tabular}

Dengan menggunakan permainan terlebih permainan tradisional Halmahera Utara pada bimbingan kelompok, anak-anak menjadi lebih akrab satu sama lain. Menurut Iswinarti (2010:41) permainan anak tradisionalmempunyai hubungan yang erat dengan perkembangan intelektual, sosial, emosi, dan kepribadian anak. Karena masa anak adalah masa yang identik dengan bermain dan terlibat dalam suatu permainan. Permainan tradisional berdampak sangat baik dalam membantu mengembangkan keterampilan emosi dan sosial anak.

Hal tersebut sesuai yang ditunjukkan oleh anak-anak di daerah pesisir Dusun Gonga Pantai pada saat diberikan perlakuan. Melalui permainan tersebut anak menjadi lebih mampu untuk bersosialasi dan mengendalikan diri serta emosinya lebih baik dalam menjalankan sebuah permainan maupun berinteraksi dengan temannya sehingga perilaku agresif yang ditunjukkan menjadi berkurang.

Hasil yang telah dicapai dalam penelitian ini memiliki potensi bahwa perilaku agresif yang terjadi di daerah pesisir dapat direduksi dengan melakukan inovasi pada salah satu layanan dalam bimbingan dan konseling yaitu bimbingan kelompok dengan menginternalisasi permainan tradisional (khas halmahera utara). Hal tersebut juga menunjukkan bahwa bimbingan dan konseling tidak hanya dapat dilakukan di sekolah pada umumnya, tetapi juga bisa dilakukan di daerah pedesaan bahkan juga menjangkau daerahpesisir.

\section{SIMPULAN}

Berdasarkan hasil yang telah dicapai, dapat disimpulkan bahwa :

a. Kondisi perilaku agresif anak di daerah pesisir rata-rata sangat tinggi dengan ditunjukkan munculnya perilaku agresif seperti Memukul, mencubit, menampar, menjahili teman, membentak, menghina, memaki, acuh tak acuh, menolak menjawab pertanyaan, mengejek, tidak mau mendengar kritikan orang lain terhadapdirinya.

b. Ada perubahan yang terjadi pada anak-anak daerah pesisir setelah mendapatkan perlakuan bimbingan kelompok dengan permainan tradisional.

c. Terjadi penuruan tingkat perilaku agresif anak setelah mendapat perlakuan.

\section{DAFTAR PUSTAKA}

Iswinarti.2010. Nilai-Nilai Terapeutik Permainan Tradisional Engklek Pada Anak Usia Sekolah Dasar. Jurnal Humanity Vol.6, Nomor 1, September 2010 : 41-44

Nur, Haerani.2013. Membangun Karakter Anak Melalui Permainan Anak Tradisional. Jurnal Pendidikan Karakter, Tahun III, Nomor 1, Februari 2013.

Patras, Yulita Rike. 2016. Permainan Anak Halmahera Utara (Games of North Halmahera Children).Yogyakarta:AG Publisher.

Petrus, Jerizal. 2012. Model Bimbingan Kelompok Berbasis Nilai-Nilai Budaya Hibualamo Untuk Meningkatkan Kecerdasan Sosial Siswa. Jurnal Bimbingan KonselingVol.1(2)(2012).

Restu, Yoshi dan Yusri. 2013. Studi Tentang Perilaku Agresif Siswa di Sekolah. Jurnal Ilmiah Konseling Vol.2 Nomor 1 Januari 2013.

Sugiyono. 2013. Metode Penelitian Kombinasi (Mixed Method). Bandung: Alfabeta.

Winkel, W.S, \& Hastuti, S. 2011. Bimbingan dan Konseling di Institusi Pendidikan. Jakarta: Gramedi 